\title{
Multipotential Phenotypic Expression of Genes Encoding Peptide Hormones in Rat Insulinoma Cell Lines
}

\author{
Jacques Philippe," William L. Chick," and Joel F. Habener ${ }^{*}$ \\ * Laboratory of Molecular Endocrinology, Massachusetts General Hospital and ${ }^{\ddagger}$ Howard Hughes Medical Institute, \\ Harvard Medical School, Boston, Massachusetts 02114; ' Departments of Biochemistry and Medicine, \\ University of Massachusetts Medical School, Worcester, Massachusetts 01605
}

\begin{abstract}
The developmental origin of the four phenotypically distinct hormone-producing islet cells (insulin, glucagon, somatostatin, pancreatic polypeptide) is unclear. To investigate the potential for phenotypic differentiation of islet cells, we prepared several clonal cell lines from a radiation-induced rat islet tumor and analyzed them for insulin, glucagon, and somatostatin gene expression by cDNA hybridization, immunocytochemistry, and radioimmunoassay. We found expression of all three genes in the tumor and in the parental cell line and mixed variable phenotypes in the clonal lines derived from the parental line. We also observed the ectopic expression of the angiotensinogen gene in the tumor and the cell lines. The relative levels of hormonal gene expression differed among the cell lines but remained fixed during continuous passage. The three islet hormone mRNAs were larger compared to the pancreas owing to longer poly(A) tracts. These observations indicate that neoplastic islet cells retain the potential to differentiate into hormone-specific cellular phenotypes and may mimic developmental pathways of the pancreatic islets.
\end{abstract}

\section{Introduction}

In a number of tissues terminally differentiated cells appear to arise from progenitor stem cells; the development of the lymphohematopoietic system is an informative illustration of this concept (1). The origin and multipotentiality of the hormone-producing islet cells of the endocrine pancreas has generated much discussion. Several hypotheses have been advanced to delineate the embryologic origins of the four peptide-producing cells of the pancreas (insulin, glucagon, somatostatin, and pancreatic polypeptide). Current evidence implicates a multipotent endodermal stem cell, capable of differentiation into enterocytes, ducts, acinar, and endocrine cells (2). Alternatively, Pearse postulated a neural origin of these cells on the basis of the APUD ${ }^{1}$ concept (amine precursor uptake and decarboxylation) (3). This concept derives from the identification of cells present in different

Address reprint requests to Dr. Philippe.

Received for publication 21 May 1986 and in revised form 12 September 1986.

1. Abbreviations used in this paper: APUD, amine precursor uptake and decarboxylation; DMEM, Dulbecco's minimal essential medium; DTT, dithiothreitol; SSC, $0.15 \mathrm{M} \mathrm{NaCl} / 0.015 \mathrm{M} \mathrm{Na}$ citrate.

J. Clin. Invest.

(c) The American Society for Clinical Investigation, Inc.

$0021-9738 / 87 / 02 / 0351 / 08 \$ 1.00$

Volume 79, February 1987, 351-358 organs whose primary function is the synthesis and release of polypeptide hormones, but which also have the capacity to synthesize biogenic amines (3). Accumulating data suggests an endodermal origin of the islet cells and indicates that neural-like characteristics can be shared by cells from different embryological origins. For instance, recent studies by Teitelman (4) have demonstrated the expression, in embryonic mice, of the catecholamine-synthesizing enzyme, tyrosine hydrolylase, which appears in a population of cells in the dorsal pancreas at day 11 of gestation. By days 12 to 14 , glucagon and tyrosine hydroxylase are colocalized in identical cells in up to $40 \%$ of the cells containing either protein. Insulin replaces glucagon in some of the tyrosine hydroxylase-positive cells at day 14 . The catecholaminergic phenotype is transient, however, and ceases after the fifteenth embryonic day $(4,5)$. The adult state of the islet cells is characterized by the presence of dopa decarboxylase which converts dopa to dopamine $(6,7)$. A common ancestor for the four peptide-producing cells of the pancreas appears to be a likely possibility.

We wished to test this hypothesis of the multipotentiality of the islet cells by analyzing the expression of several genes encoding polypeptide hormones in clonal and subclonal cell lines derived from a transplantable rat insulinoma $(8,9)$. These cells have the capacity to synthesize biogenic amines because of their high content of L-dopa decarboxylase (10). In addition, because these insulinoma cell lines are transformed cells they are likely to be partially dedifferentiated, and thus be capable of phenotypic switching in the expression of the hormone genes. We show here that a tumor derived from a predominantly somatostatin-producing cell line, first cloned as an individual cell, expresses the insulin, glucagon, and angiotensinogen genes, as well as retaining its somatostatin phenotype. Furthermore, analyses of messenger RNA and hormone synthesis by immunocytochemistry and radioimmunoassays by clonal cell lines derived from the transplanted tumor, as well as unrelated cell lines isolated independently, support the conclusion that a single, transformed islet cell has the potentiality of differentiating into cells expressing at least three of the islet hormones.

\section{Methods}

Tumor and origins of cell lines. The lineage of the tumor and the cell lines analyzed in this study is illustrated in Fig. 1. The original rat islet cell tumor arose following 1000 rad of total body $\mathrm{x}$-irradiation to a inbred albino NEDH rat (8). It was then developed into a serially transplantable tumor in NEDH rats. Individual cells were subsequently cloned from the parent cell line (RIN-r), derived from this serially transplantable tumor line (9). Some representative clones $(1046-38,1046-44)$ as well as a separate chemically induced solid tumor (S2181) (14) were further analyzed in this study. An additional cell line (1027-B $\mathbf{B}_{2}$ ), expressing predominantly, somatostatin, was injected subcutaneously in four NEDH rats. 3 wk later, the tumors (T1056) were removed and either used for 


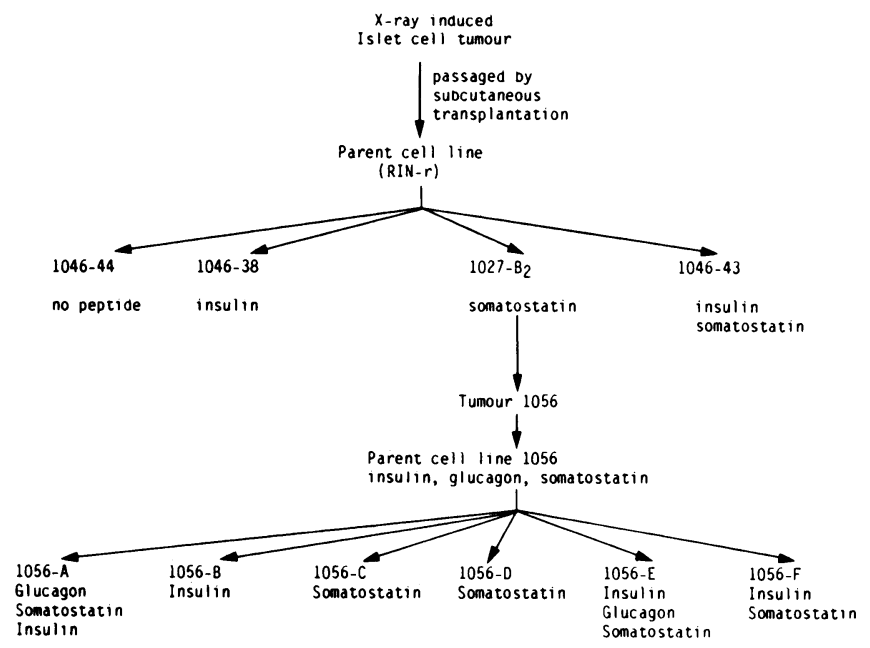

Figure 1. Lineage of the islet tumors and cell lines starting from the original $\mathrm{x}$-ray induced islet cell tumor. Hormones secreted by each clonal cell line, as measured in the medium by radioimmunoassay, and the identification number of the specific clones used in the study are indicated.

RNA extraction or to establish continuous cell lines (1056). Individual cells were, eventually, cloned by limiting dilutions from the parent 1056 cell line and analyzed for expression of specific mRNAs and peptide synthesis.

Cell culture and tumor propagation. The cell lines used in these studies were derived from a continuous islet cell line, RIN-r, which was established from a transplantable rat islet cell tumor (9). For the present experiments, the cells were maintained in Dulbecco's minimal essential medium (DMEM) (Gibco Laboratories, Grand Island, NY) at a glucose concentration of $4,500 \mathrm{mg} / \mathrm{liter}$, and supplemented with $10 \%$ heat-inactivated fetal bovine serum (Gibco Laboratories), $100 \mathrm{U} / \mathrm{ml}$ of penicillin and $100 \mu \mathrm{g} / \mathrm{ml}$ of streptomycin. Incubations were carried out at $37^{\circ} \mathrm{C}$ in $95 \%$ air:5\% $\mathrm{CO}_{2}$. Cell lines 1027- $\mathrm{B}_{2}, 1046-44$, and 1046-38 were cloned from the parent cell line and propagated to mass culture.

Clone $1027-B_{2}$, established as a somatostatin-producing cell line, was injected subcutaneously $\left(\sim 4 \times 10^{7}\right.$ cells $)$ into the interscapular area of four albino inbred NEDH rats. $20 \mathrm{~d}$ later, tumors were removed aseptically, minced, and trypsinized in order to develop continuous cell lines, or frozen in liquid nitrogen and stored at $-70^{\circ} \mathrm{C}$ for RNA extraction. Fibroblast cells were eliminated by transferring freshly trypsinized cells to new dishes.

RNA extraction and Northern blot analysis. Total RNA was extracted from solid tumors and cells by homogenization in guanidine thiocyanate and sedimentation through a cesium chloride cushion (12). Poly $\mathrm{A}^{+}$ RNA was isolated by oligo dT cellulose chromatography (13). $20 \mu \mathrm{g}$ of total RNA from each sample was size fractionated on a $1.4 \%$ agarose gel after denaturation in glyoxal followed by electrotransfer to a nylon membrane (Nytran, Schleicher and Schuell, Keene, NH). Blots were baked for $2 \mathrm{~h}$ at $80^{\circ} \mathrm{C}$ under vacuum, prehybridized in $1 \mathrm{M} \mathrm{NaCl} / 1 \%$ SDS $/ 10 \%$ Dextran sulfate at $50^{\circ} \mathrm{C}$ overnight and hybridized at the same temperature for $24 \mathrm{~h}$ after addition of the labeled probes $\left(3-5 \times 10^{5}\right.$ $\mathrm{cpm} / \mathrm{ml})$; they were then washed at $55^{\circ} \mathrm{C}$ twice in $1 \times \mathrm{SSC}(0.15 \mathrm{M} \mathrm{NaCl} /$ $0.015 \mathrm{M} \mathrm{Na}$ citrate)/ $1 \%$ sodium dodecyl sulfate (SDS) and exposed for varying times at $-70^{\circ} \mathrm{C}$ with an intensifying screen.

Preparation and radiolabeling of oligonucleotides. Oligonucleotides from 26 to 43 bases, complementary to different regions of each of the messenger (m)RNAs, (six each for glucagon, somatostatin, and angiotensinogen and four for insulin) were synthesized by an automated oligonucleotide synthesizer (Applied Biosystems, Foster City, CA). The cDNAs were 5 'end-labeled with $\left.{ }^{32} \mathrm{P}\right] \mathrm{ATP}$ by $\mathrm{T}_{4}$-polynucleotide kinase (Bethesda Research Laboratories, Gaithersburg, MD) to a specific activity of $1-2 \times 10^{8} \mathrm{cpm} / \mu \mathrm{g}$.
Primer extension assay. The primers were synthetic oligonucleotides cDNAs, as described above, and chosen to have biosynthetic extended fragments of $<250$ bases in length; they were labeled as above. DNARNA hybridization was performed in a final volume of $10 \mu \mathrm{l}$ containing $200 \mathrm{mM} \mathrm{KCl}, 100 \mathrm{mM}$ Tris $\mathrm{HCl}$ (pH 8), $1 \mathrm{mM}$ EDTA, 1 pmol of endlabeled primer and 25-50 $\mu \mathrm{g}$ of total RNA. The reaction mixture was denatured at $100^{\circ} \mathrm{C}$ for $5 \mathrm{~min}$ and incubated at $50^{\circ} \mathrm{C}$ for $3 \mathrm{~h}$. Extension was carried out in $25 \mu \mathrm{l}$ of $80 \mathrm{mM} \mathrm{KCl}, 40 \mathrm{mM}$ Tris- $\mathrm{HCl}(\mathrm{pH} 8.0), 1$ mM EDTA, $8 \mathrm{mM}$ dithiothreitol (DTT), $8 \mathrm{mM} \mathrm{MgCl}, 1 \mathrm{mM}$ of each dNTP and $40 \mathrm{U}$ of reverse transcriptase (Life Sciences, Inc., Bayport, $\mathrm{NY}$ ) at $42^{\circ} \mathrm{C}$ for $1 \mathrm{~h}$. The extended fragments were purified by phenol extraction, treated with $0.2 \mathrm{~N} \mathrm{NaOH}$ at $65^{\circ} \mathrm{C}$ for $1 \mathrm{~h}$ and dried down, before they were run on a 5 or $20 \%$ (depending on the size of the expected readout) polyacrylamide gel containing $7 \mathrm{M}$ urea.

RNAse $H$ digestion of poly $(A)$ tracts. 50 to $100 \mu \mathrm{g}$ of total RNA were hybridized to $10 \mu \mathrm{g}$ of d(pT) 12-18 (Collaborative Research, Inc., Lexington, MA) in $100 \mathrm{mM} \mathrm{KCl}$ at $37^{\circ} \mathrm{C}$ for $30 \mathrm{~min}$, after denaturation at $65^{\circ} \mathrm{C}$ for $2 \mathrm{~min}$; $2 \mathrm{U}$ of RNAse $\mathrm{H}$ (Bethesda Research Laboratories) were then added in $80 \mathrm{mM} \mathrm{KCl}, 40 \mathrm{mM}$ Tris- $\mathrm{HCl} \mathrm{pH} \mathrm{7.9,} 5 \mathrm{mM} \mathrm{MgCl}_{2}$, $1 \mathrm{mM}$ DTT, $0.5 \mathrm{mg} / \mathrm{ml}$ bovine serum albumin (BSA) and the reaction was carried on for $30 \mathrm{~min}$. The RNA was phenol-extracted, ethanolprecipitated, and run on agarose gels as described above.

Immunocytochemistry. RIN cells were grown on glass slides. Slides were rinsed in phosphate-buffered saline (PBS), then fixed for $20 \mathrm{~min}$ in 4\% paraformaldehyde in PBS, washed for $10 \mathrm{~min}$ in three consecutive batches of PBS, then dipped in water, air-dried, and stored at $-80^{\circ} \mathrm{C}$.

Serum containing biotinylated antibodies (dilution $1 / 100$ ) was applied to the cells along with 2 drops of $100 \mu \mathrm{g} / \mathrm{ml}$ Avidin D in PBS; after 30 min, slides were drained and covered with primary antibodies (glucagon-, insulin-, and somatostatin-specific antibodies) diluted in PBS and incubated overnight at $4^{\circ} \mathrm{C}$. After a 30-min wash in PBS, endogenous peroxidase was blocked in a $0.3 \%$ solution of $\mathrm{H}_{2} \mathrm{O}_{2}$ with $20 \mu \mathrm{g} / \mathrm{ml}$ of Biotin (in PBS) for $30 \mathrm{~min}$. The slides were then washed and incubated with the biotinylated second step antibody (Vectastain Kit, Vector Lab, Burlingame, CA) for $30 \mathrm{~min}$, washed again and incubated with the avidinbiotinylated horseradish peroxidase complex for $45 \mathrm{~min}$. After a final wash, slides were soaked in the staining mixture $(0.1 \mathrm{M}$ sodium acetate, $\mathrm{pH} 5.0$, containing $0.015 \%$ dimethyl formamide and $0.02 \%$ of $\mathrm{H}_{2} \mathrm{O}_{2}$, $0.5 \%$ formamide and $0.02 \%(\mathrm{wt} / \mathrm{vol}$ ) 3-amino-9-ethylcarbazole) for 3 $\mathrm{min}$, rinsed, and counterstained in hematoxylin for $1 \mathrm{~min}$, dipped in saturated lithium carbonate and mounted in Glycergel (Dako Corp., Santa Barbara, CA). The antibodies were GLP-1 (B-5) at a dilution of 1:500 for glucagon (14), insulin specific (from Ling Research, Latham, NY) at a dilution of 1:200 and somatostatin specific (from Immunonuclear, Stillwater, MN) at a dilution of 1:200. Control slides were treated similarly with antisera that had been preabsorbed with GLP-I, insulin, and somatostatin and immunocytochemical analyses of rat pancreas were carried out in parallel.

Radioimmunoassay. Insulin, glucagon, and somatostatin were measured in the cell culture medium by radioimmunoassays, as previously described $(9,14)$.

\section{Results}

Morphology of the islet cell lines. Despite their common origin, the morphologic features and the growth rate of the different cell lines differ markedly. As shown in Fig. $2 A, 1027-\mathrm{B}_{2}$, the progenitor of 1056 (Fig. $2 \mathrm{~B}$ ), grows in clusters with well-defined margins and only rare cytoplasmic processes extending from free cell surfaces; 1046-38 has similar morphological features (Fig. $2 C$ ). Clone 1046-44 grows as isolated cells until they reach confluence (Fig. $2 \mathrm{D}$ ). The growth rate of 1046-38 and 1046-44 clones is about twice as fast as that of 1056 and 1027-B2 (doubling time $\sim 24 \mathrm{~h}$ ).

In contrast, 1056 consists of elongated cells with cytoplasmic processes characteristically extending from free cell surfaces (Fig. $2 B$ ). Its appearance is remarkably similar to that of RIN-r and 

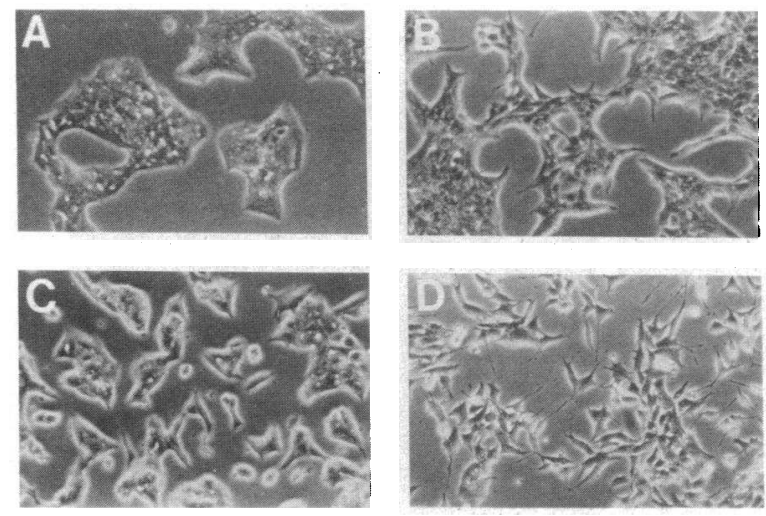

Figure 2. Light photomicrograph of different RIN clonal cell lines in culture. $(A)$ clone 1027- $\mathrm{B}_{2},(B)$ clone $1056,(C)$ clone 1046-38, $(D)$ clone 1046-44 $(\times 80)$.

RIN-m, the first islet cell lines originally reported (9). The population doubling time is $48 \mathrm{~h}$ (as measured by DNA content) compared to $52 \mathrm{~h}$ for RIN-r. Clones derived from 1056 had similar morphologic characteristics to the parent cell line. The morphological features do not appear to correspond to any defined phenotype and thus seem independent of what the cells secrete.

Phenotypic expression of the tumor and cell lines. Expression of the genes coding for insulin, glucagon, and somatostatin was assessed by messenger RNA analysis and by measuring their translational products by immunocytochemical analyses of the cells and radioimmunoassay of the culture medium. After electrophoresis and transfer to a nylon membrane, total RNA was hybridized to synthetic oligonucleotide cDNA probes; four cDNAs were complimentary to the rat insulin genes, and six to the rat glucagon gene. cDNAs matched each of the six exons of the glucagon gene and six cDNAs matched the two exons of the rat somatostatin gene. In preliminary experiments, the cDNA probes were used one by one to ascertain the authenticity of the mRNA analyzed by demonstrating that each cDNA individually hybridized strongly to the specific mRNAs (data not shown).

We found marked variability in the phenotypic expression of the tumor and cell lines derived from clone 1027-B2 (Fig. 3). Two additional representative cell lines, previously cloned from RIN-r (1046-38 and 1046-44) and a solid tumor with a mixed insulin-somatostatin phenotype (S2181) are also represented. Although as a cell line, clone $1027-\mathrm{B}_{2}$ expresses predominantly somatostatin, once it forms a solid, subcutaneous tumor in the rat host it is capable of differentiation and expresses all three islet hormones studied. The cell line derived from tumor 1056 retains a phenotypic pattern of gene expression that is similar to that of the tumor.

One of the subclonal cell lines, 1056A, expressed the glucagon gene at a particularly high level and represents a predominantly A-cell phenotype. This cell line produces large amounts of glucagon and the glucagon-like peptides processed from proglucagon (15). The cloning of individual cells from the parent line, 1056, provided several continuous cell lines, each expressing different hormone phenotypes (Fig. 3). These cell lines have exhibited stable phenotypic expression of the genes analyzed for $\sim 1 \mathrm{yr}$. Secondary single cell cloning from $1056 \mathrm{~A}$ revealed the same qualitative and quantitative variability of polypeptide hormone gene expression as the primary cloning.
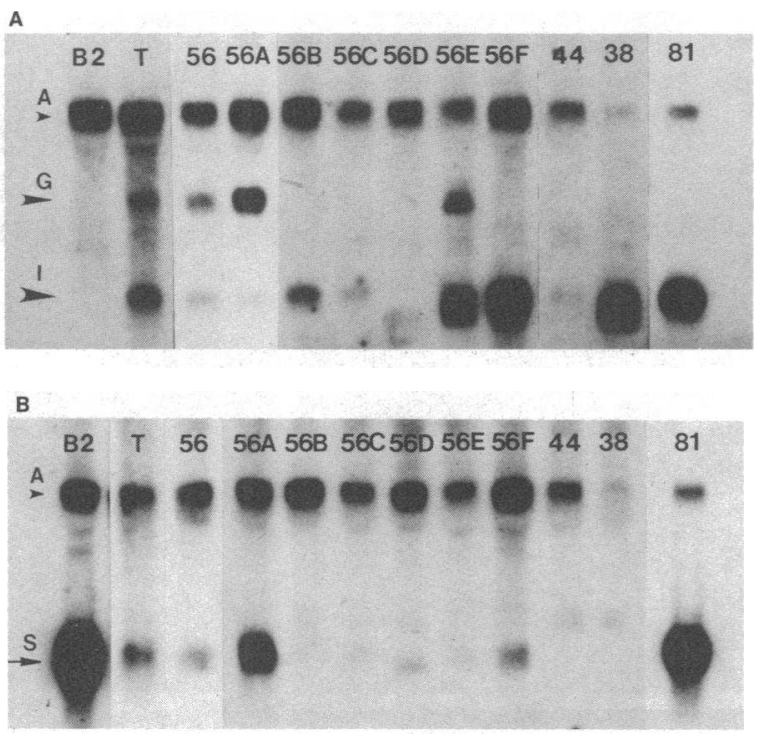

Figure 3. RNA analyses by Northern blots of the different tumor and cell lines. Each lane contains $20 \mu \mathrm{g}$ of total cellular RNA. Blots were hybridized with oligonucleotide cDNA probes complementary to insulin, glucagon, and angiotensinogen mRNAs $(A)$. After washing off the above probes the blots were rehybridized with cDNAs to angiotensinogen and somatostatin $(B)$ (see Methods). Blots were exposed for $12 \mathrm{~h}$, except lane $81(2 \mathrm{~h}) . A$ points to the angiotensinogen mRNA, $G$ to the glucagon mRNA, $I$ to the insulin mRNA, and $S$ to the stomatostatin mRNA. $B_{2}$ : 1027-B . T: tumor 1056: 56: parental 1056 cell line. 56 A-56F: 1056A-1056F. 38: 1046-38. 44: 1046-44. 81: S2181.

Of the three representative phenotypes of clones previously established (9), 1046-38 illustrate the insulinoma phenotype (no detectable expression of the glucagon and somatostatin genes by mRNA analysis and only rare glucagon-positive cells by immunocytochemistry), the amount of insulin mRNA expressed differing by 60 -fold when compared with $1046-44$. Tumor S2181 represents the mixed insulin-somatostatin phenotype, expressing roughly equivalent levels of insulin and somatostatin mRNAs and 6-fold as much as the highest insulin-producing cell line analyzed.

Immunocytochemical analyses of the various clonal cell lines revealed that the expression of detectable hormone antigens is limited to selected subpopulations of cells (Fig. 4). Approximately $10-20 \%$ of the cells are strongly immunopositive and the remainder are immunonegative; there do not appear to be any intermediate cells. Further, the immunopositive cells occur in groups among a background of nonhormone producing cells suggesting the existence of some form of "organizer" activities. With regard to the relative abundances and distributions of the glucagon and somatostatin-specific cell phenotypes, the clonal lines $1056 \mathrm{~A}$ and $1027-\mathrm{B}_{2}$ appear to be "mirror images" of each other inasmuch as $1056 \mathrm{~A}$ contains a rather uniform distribution of glucagon-positive cells with rare nests of somatostatin-positive cells and $1027-B_{2}$ is just the reverse of this. It is difficult to quantitate these relative distributions but in the $1056 \mathrm{~A}$ and $1027-\mathrm{B}_{2}$ lines every medium power field $(\times 100)$ has numerous glucagon or somatostatin cells, respectively. The occurrence of small nests ( $\sim$ 3-10 cells) of somatostatin or glucagon cells appear on the average of every 10-12 fields. The presence of insulin-positive cells is rare in 1056A; on an entire slide only a few insulin cells were seen. 

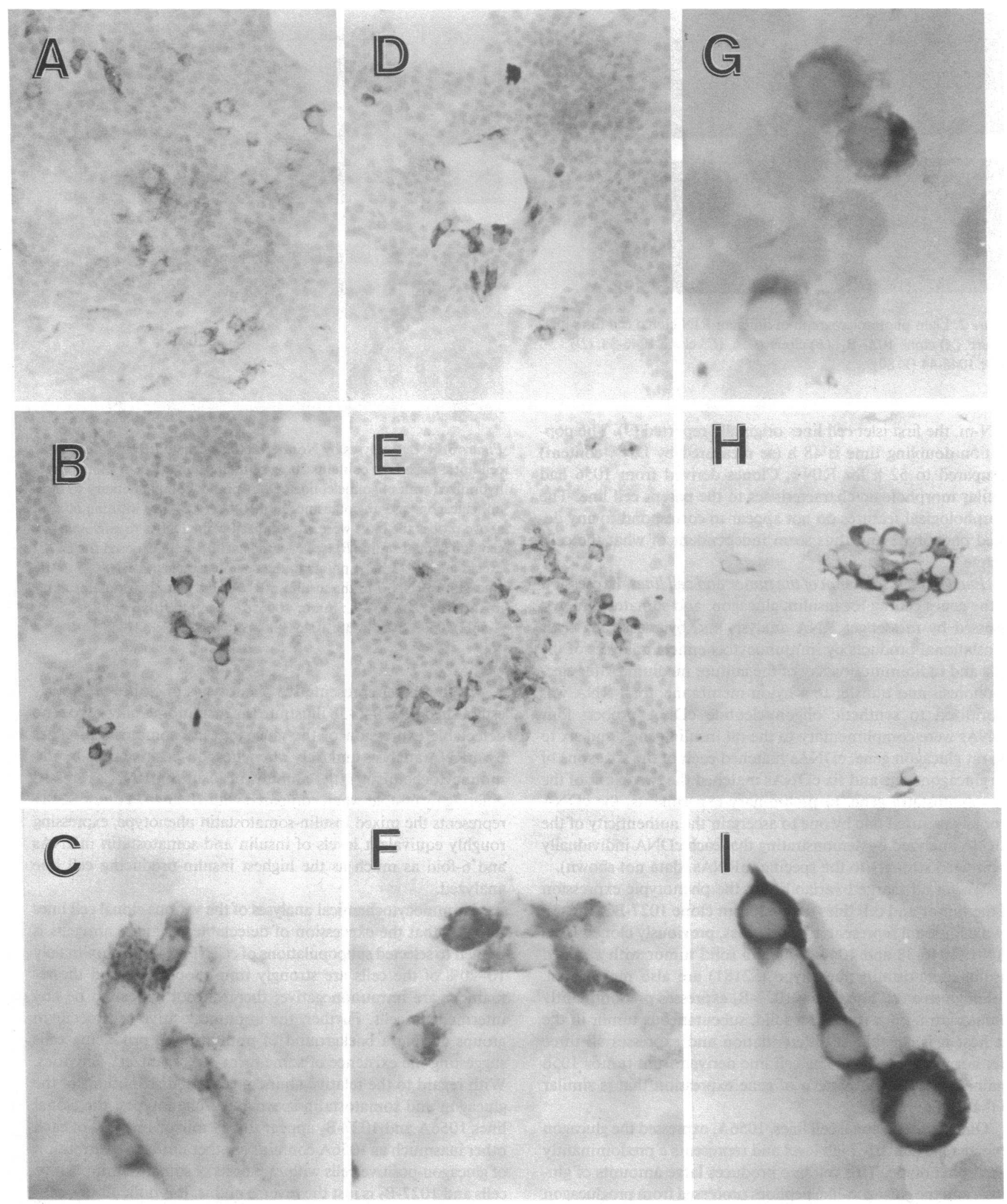

Figure 4. Immunocytochemical staining of rat islet cell lines. The various cell lines were grown on glass slides and stained with antisera to either glucagon, insulin or somatostatin using the Avidin-Biotin-peroxidase technique as described in Methods. Note the existence of a mixed heterogenity of hormone-specific cell phenotypes. The cells are either strongly immunopositive or are immunonegative, the positive cells occur in groups and constitute the minority of the cell populations. $A, I, D, G$; cell line 1056A. B, E, F, cell line 1027- $\mathrm{B}_{2} . H, I$; cell line 1046-38. $A-C$, stained with antiserum to glucagon-like peptide I; $D-F$, stained with antiserum to somatostatin, $G-I$, stained with antiserum to insulin. Magnifications: $A, B, D, E, H, \times 300 . C, F, G, I, \times$ 1200. 
It is intriguing that these peculiar mixed phenotypes of hormone-positive cells appears to remain fixed inasmuch as these precise patterns of distributions of the cells has remained unchanged over at least 3-4 mo of repeated immunocytochemical analyses. Furthermore, the relative amounts of the different hormone-positive cells correlates well with the relative expression of the genes as measured by both mRNA hybridization and radioimmunoassays.

Translational products of the specific mRNAs were measured by radioimmunoassay of the culture medium and the results are expressed per $10^{6}$ cells $/ 24 \mathrm{~h}$ (Table I). There is a good correlation between the relative abundance of the different mRNAs and hormone concentrations in the different cell lines.

A comparison of hormone gene expression between the tumor, the cell lines and rat adult pancreas were assessed from mRNA and immunocytochemical analyses. The intensity of immunocytochemical staining was roughly equivalent (within two- to threefold) between positive neoplastic and normal islet cells for all three hormones: insulin, glucagon, and somatostatin. The insulin mRNA content of the tumor 1056, the cell line 1056B and the adult pancreas were comparable. However, both glucagon and somatostatin mRNA levels were higher in the tumor and cell line $1056 \mathrm{~A}$ than in the pancreas. Considering that islet tissue accounts for only $1 \%$ of the pancreas weight, these observations indicate that the few percent of the islet cells that express the hormone genes, express them at approximately the same levels as they are expressed in normal rat islets.

Characterization of the $m R N A s$. Somewhat surprisingly, we observed that all three mRNAs coding for insulin, glucagon, and somatostatin, isolated from either tumor or cell lines, are larger by 100 to 300 bases when compared with the mRNAs extracted from normal rat pancreas. We reasoned that the two most likely explanations to account for the larger sizes of the mRNAs were utilization of a different upstream transcriptional start site and/or the presence of a longer $3^{\prime}$ polyadenylation tract.
We investigated the first possibility by oligonucleotide-primed reverse transcription of the large mRNAs using reverse transcriptase and compared their transcriptional startpoints to those of the mRNAs in normal pancreas. Both insulin and somatostatin mRNAs were analyzed in this manner and the transcriptional start sites were identical in the cell lines and pancreas (Fig. $5 B$ and $5 C$ ). We addressed the second hypothesis by using RNAse $\mathrm{H}$, an endoribonuclease which specifically degrades the RNA portion of an RNA-DNA hybrid. Thus, we hybridized synthetic poly (dT) oligonucleotides to the poly (A) tracts of the mRNAs extracted from both cell lines and pancreas before RNAse $\mathrm{H}$ digestion and analyzed the sizes of the resulting mRNAs by Northern blot hybridizations (Fig. 6). The larger size of the glucagon, somatostatin, and insulin mRNAs in the cell lines is entirely due to a longer en bloc segment of poly A because after RNAse digestion the mRNAs are reduced to a size identical to the RNAse $\mathrm{H}$ treated pancreatic mRNAs (Fig. 6). It is of interest to note that the phenomenon of longer poly (A) tracts appears to be specific for these mRNAs encoding secreted proteins; we did not observe any differences in the sizes of mRNAs encoding $\beta$-actin and the c-myc protein in the cell lines compared to pancreas (data not shown).

Ectopic expression of angiotensinogen in islet cell lines. Because tumors are known to ectopically express hormones, we used a mixture of cDNA oligonucleotides to a number of mRNAs encoding peptide hormones to screen total RNA extracted from the different cell lines for the expression of mRNAs encoding calcitonin, vasopressin, oxytocin, atrial natriuretic peptide, gastrin-releasing peptide, insulinlike growth factors I and II, proopiomelanocortin, growth hormone-releasing hormone, and angiotensinogen. We detected only angiotensinogen mRNA. To confirm this finding, we used exon-specific probes one by one to demonstrate the authenticity of the mRNA; probes for all five exons hybridizes to the mRNA (data not shown). The angiotensinogen gene is expressed in every islet cell line that

Table I. Relative Levels of Immunoreactive Hormones and mRNAs in Clonal Islet Cell Lines

\begin{tabular}{|c|c|c|c|c|c|c|}
\hline & \multicolumn{3}{|c|}{ Immunoreactive hormones } & \multicolumn{3}{|l|}{ mRNA } \\
\hline & $\begin{array}{l}\text { Insulin } \\
\left(\mu \mathrm{U} / 10^{6} \text { cells }\right)\end{array}$ & $\begin{array}{l}\text { Glucagon } \\
\text { (pg/10 cells) }\end{array}$ & $\begin{array}{l}\text { Somatostatin } \\
\text { (pg/10 cells) }\end{array}$ & $\begin{array}{l}\text { Insulin } \\
\text { (RU) }\end{array}$ & $\begin{array}{l}\text { Glucagon } \\
\text { (RU) }\end{array}$ & $\begin{array}{l}\text { Somatostatin } \\
\text { (RU) }\end{array}$ \\
\hline & $\%$ & $\%$ & $\%$ & $\%$ & $\%$ & $\%$ \\
\hline $1027-B_{2}$ & - & - & $63,300(100)$ & - & - & $120 \quad(100)$ \\
\hline 1056 & $107(2.2)$ & $283(31)$ & $540(1)$ & $1 \quad(2)$ & $3(25)$ & $2.5(2)$ \\
\hline 1056-A & $115(2.4)$ & $854(100)$ & $4,325(7)$ & $0.5(1)$ & $12(100)$ & $15 \quad(12)$ \\
\hline 1056-B & $504(10.5)$ & - & - & $5 \quad(10)$ & - & - \\
\hline $1056-\mathrm{C}$ & - & - & $630(1)$ & $1 \quad(2)$ & - & $0.3(0.2)$ \\
\hline 1056-D & - & - & $959(1.5)$ & - & - & $1 \quad(0.8)$ \\
\hline $1056-\mathrm{E}$ & $1,712(40)$ & $535(62.6)$ & $430(0.4)$ & $26 \quad(48)$ & $6(50)$ & $0.3(0.2)$ \\
\hline $1056-\mathrm{F}$ & $4,368(91)$ & - & $2,083(1.8)$ & $54 \quad(100)$ & - & $3(2.4)$ \\
\hline $1046-44$ & $109(2.2)$ & - & - & $0.8(1.5)$ & - & - \\
\hline $1046-38$ & $4,811(100)$ & - & - & $48 \quad(89)$ & - & - \\
\hline
\end{tabular}

(Left) Immunoreactive insulin, glucagon, and somatostatin secretion from the different clonal cell line. Secretion per $10^{6}$ cells $/ 24 \mathrm{~h}$. Relative percent of the amount of each peptide as compared to its highest equivalent (taken as 100\%) is indicated in parentheses. (Right) Amount of insulin, glucagon, and somatostatin mRNA from the different clonal cell line, expressed in relative OD unit (RU), as quantitated by densitometric scanning of autoradiograms. Relative percent of the amount of each mRNA as compared to its highest equivalent (taken as $100 \%$ ) is indicated in parentheses. Both RNA and medium come from the same plates and there is a $10-20 \%$ variation in the amounts of specific mRNA levels and peptides from plate to plate. The sensitivity of the radioimmunoassays is: $100 \mu \mathrm{U} / \mathrm{ml}$ for insulin, $50 \mathrm{pg} / \mathrm{ml}$ for somatostatin and $20 \mathrm{pg} / \mathrm{ml}$ for glucagon. 


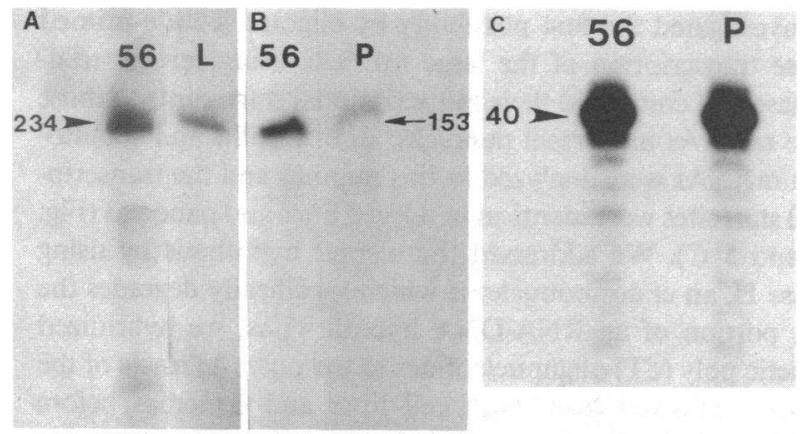

Figure 5. Primer extension analysis of angiotensinogen mRNA from 1056 and liver $(A)$ and of insulin and somatostatin mRNAs from 1056 and pancreas ( $B$ and $C$, respectively). A synthetic oligonucleotide cDNA of 38 bases was hybridized to the angiotensinogen mRNA 234 bases $3^{\prime}$ from the cap site and synthesis of the complementary DNA was allowed by addition of reverse transcriptase and dNTPs; the extension analysis was analogous for the insulin and somatostatin mRNAs, using a 32-base cDNA probe hybridizing 153 bases $3^{\prime}$ and a 30 base cDNA probe hybridizing 40 bases $3^{\prime}$ from the cap site, respectively. $25 \mu \mathrm{g}$ of liver, 1056 and pancreas total RNA were used, except $50 \mu \mathrm{g}$ of pancreas RNA in $(C)$. cDNAs were analyzed on a $5 \%(A$ and $B)$ and $20 \%(C)$ sequencing gel.

we have analyzed so far (Fig. 3 and data not shown), albeit at different levels. By contrast, the angiotensinogen mRNA was undetectable in the rat pancreas both by Northern analysis of poly $\left(\mathrm{A}^{+}\right) \mathrm{RNA}$ and by $\mathrm{S} 1$ nuclease analysis (16).

Just as we found for the $m R$ NAs encoding insulin, glucagon, and somatostatin, the size of the angiotensinogen mRNA was larger compared to the normal liver mRNA. A primer readout study indicated identical transcriptional start sites for both islet cell and liver mRNA (Fig. $5 A$ ). Further treatment of the RNA with additional amounts of RNAse $H$ failed to reduce the size of the mRNA to that of the liver mRNA treated similarly, indicating that the poly (A) tract was not entirely responsible for the increase in size of the islet mRNA. Because the rat angiotensinogen gene has four polyadenylation sites (17), we hypothesize that one of the distant sites might be used during transcription. Although liver angiotensinogen mRNA predominantly uses the second polyadenylation site (at 1784-1786 nucleotides)

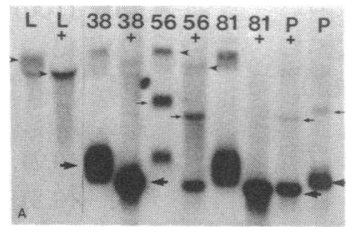

Figure 6. Northern blot of RNAse Htreated RNA from tumor and cell lines. Each control lane contains $20 \mu \mathrm{g}$ of total cellular RNA except lane $P$ of (B) ( $2 \mu \mathrm{g}$ of poly $\mathrm{A}^{+}$RNA) (the amount of RNA in the RNAse $H$ varies from 5 to $16 \mu \mathrm{g}$ ). Blots were hybridized as described in Fig. 3 and exposed for $4 \mathrm{~h}$, except the four first lanes $(12 \mathrm{~h})$ and the last two lanes (1 h) of $(B) .1056$ was treated with sodium butyrate $2 \mathrm{mM}$ for $72 \mathrm{~h}$ to increase insulin steady state mRNA (39). + indicate RNAse H-treated samples (see Methods) $\rightarrow$ points to angiotensinogen mRNA $\rightarrow$ to glucagon mRNA $\Rightarrow$ to insulin mRNA and $\Rightarrow$ to somatostatin mRNA. $L$, liver; $38,1046-38 ; 56,1056 ; 81$, S3181; $P$, pancreas.
(17) it also uses the third site (at 1800-1803 nucleotides), as found by hybridization with an oligonucleotide complementary to nucleotides 1794-1837. Inasmuch as the angiotensinogen mRNA expressed in the islet cells is still larger than this latter component by $\sim 50$ nucleotides, it probably uses the last polyadenylation sites at $1839-1842$ nucleotides.

\section{Discussion}

Our results demonstrate the multipotential phenotypic capability of an individual transformed rat islet cell. Originally, to obtain single phenotype cell lines, multiple clones were developed from RIN-r, the parental cell line, and analyzed in regard to the hormones secreted (9). Although most of the clones secreted both insulin and somatostatin, a finding reported by others (10) and already suggesting the multipotentiality of these cells, insulinand somatostatin-secreting clones were obtained, as well as cells which did not produce either of two hormones.

A somatostatin-secreting clone, $1027-\mathrm{B}_{2}$, was injected subcutaneously in rats. Solid tumors of $2-3 \mathrm{~cm}$ in size developed at the site of injection after 3 wk. Not unexpectedly, blood glucose, checked on several occasions, remained within normal limits. Analysis of mRNA encoding insulin, glucagon, and somatostatin both from the tumor and the parent cell line, (1056) derived from it, revealed expression of all three genes. Of interest was the fact that none of these three genes was highly expressed and that the relative abundance of the mRNAs, as measured by autoradiographic microdensitometry, was roughly equivalent. Thus, no dominant phenotype emerged from the tumor despite the characteristics of its progenitor.

When we analyzed expression of the same genes in islet cell lines, obtained from single cloned cells, we observed a wide variety of different phenotypes; from cells of a single phenotype (1046-38, 1056B) representing a small minority of the clones, to cells expressing two or all of the three genes (1056 A, E, F). The same multipotential capability, as seen in the in vivo study, can thus be manifested during in vitro culture. The implication of these results is that cloned islet cells have given rise to cultures (or tumors) containing mixtures of cells of different phenotypes, each expressing one hormone.

We not only selected these various cell clones to illustrate their different and multiple phenotypes, but also to emphasize the large differences in the amounts of hormones synthesized by them. As an example, there was a 110-fold difference in insulin mRNA between the highest and the lowest insulin-producing clones; we have also seen this variability in solid tumors. It appears from the immunocytochemical analysis that the variability in quantitative gene expression can be accounted for, at least in part, by the different relative numbers of hormone-expressing cells. The topographical arrangement of the hormone-producing cells in the clonal lines is intriguing. Although only a minority $(10-20 \%)$ of cells in any given cell line expressed a hormone gene as determined by immunocytochemical analyses, the immunopositive cells were not uniformly dispersed throughout the cell population but rather occurred in clusters. In the 1056A line the glucagon-expressing cells were dispersed abundantly throughout the population of cells whereas somatostatin-expressing cells appeared rarely in small nests of a few cells. This topography in the $1027-\mathrm{B}_{2}$ line was just the reverse; somatostatin cells were dispersed throughout and glucagon cells appeared in occasional small clusters, yet the 1056A line was cloned from 
the $1027-\mathrm{B}_{2}$ line. These observations clearly suggest that these cell lines are expressing some kind of "organizer" principles be they either indirect diffusible factors or direct cell contact phenomena to explain the existence of such mixed, fixed hormone phenotypes. The question arises regarding whether or not a given cell expressed more than one hormone gene. Because of the marked differences in the topographical arrangements of the glucagon- and somatostatin-expressing cells we can say with certainty that in the 1056A lines there exist glucagon-expressing cells that do not express either somatostatin or insulin, and in the 1027- $\mathrm{B}_{2}$ line most of the cells expressing somatostatin do not express glucagon. However, whether or not the minor cell populations, somatostatin in $1056 \mathrm{~A}$ and glucagon in $1027-\mathrm{B}_{2}$ express glucagon, somatostatin (or insulin), respectively, remains unknown and must await the completion of colocalization, dual immunostaining of single cells.

The clinical relevance of the totipotency of malignant islet cells is illustrated by the frequent occurrence of pancreatic islet tumors producing several peptide hormones (18). A metastatic tumor, predominantly containing glucagon, has even been identified in the liver of a patient with a malignant insulinoma (19).

It is tempting to relate the multipotentiality of neoplastic islet cells to the developmental pathway of differentiation of normal islets. Several lines of evidence indicate that islet cells arise from a common stem cell, endodermal $(2,20)$ in origin. Our neoplastic cells may have reverted to a primitive precursor state and retained the potential to differentiate into the different islet cell phenotypes. This potential appears to be expressed during cell growth whether in vivo or in vitro. The fact that these cell lines derived from single cloned cells can secrete multiple hormones, is illustrative of their multipotentiality. It should not be considered, however, as a true differentiation event as these cells can always express their multipotency.

Embryonic development proceeds from multiple successive steps, during which cells acquire certain determinants and become committed. A common endodermal $(20,21)$ stem cell may give rise to endocrine cells of both the pancreas and gut epithelium. Some of the determinants acquired during development may be shared by terminally differentiated cells from different embryological origins, which might explain the APUD characteristics of the islet cells. Several observations illustrate the presence of neural phenotypic markers in tissues not derived from the neural crest. Coexpression of neuron-specific markers along with polypeptide hormones in cells of the endocrine system, has been reported: $(a)$ the presence of tyrosine hydroxylase in glucagon- and insulin-containing cells of the embryonic mouse pancreas (4) and (b) of synaptophysin, a membrane glycoprotein of presynaptic vesicles in several endocrine epithelial cell types, including the pancreatic islets (22); (c) a nerve cell enzyme, neuron-specific enolase, is detected in a wide variety of tumors derived from neural and foregut endocrine cells $(23,24)$. Some of the neural characteristics have been retained by the neoplastic islet cells such as L-dopa decarboxylase (10) indicating that the acquisition of this property occurs early during development.

The large increase in the poly(A) tract of the insulin, glucagon and somatostatin mRNAs found in these cells is intriguing. Most eukaryotic $\mathrm{mRNA}$ species have a sequence of adenylic acid residues added to the $3^{\prime}$ ends; newly synthesized mRNAs have poly(A) tracts of 150-200 nucleotides that are shortened to 4060 within a few hours; the shortening of the poly (A) tract apparently stops once the tract has reached $30-40$ nucleotides (25). The precise reasons for the existence of the poly (A) tract are still unclear, but a number of recent investigations have shed some light on its potential role. Two major functions have been proposed: stabilization of mRNAs and increased translational efficiency (26-30). The fact that among six different mRNAs analyzed only the three encoding the islet hormone mRNAs have a longer poly (A) tract is even more intriguing. The analogy to the primitive islet cells can again be drawn. During fetal development, the cells might have used the advantages provided by a long poly (A) tract to enhance translational efficiency, as has been reported in other systems $(27,28)$; the 900 -fold increase in insulin mRNA, accompanied by a correspondent rise in insulin that occurs during rat fetal pancreatic development (31) may be possible, in part, by increased mRNA stability.

It should be noted that increased polyadenylation of the insulin mRNA has also been noted in rat yolk sac and in a rat insulinoma line (RIN 5F) $(31,32)$. The extra polyadenylation of the insulin mRNA in the 5F line appeared to be dependent upon matrix substrata upon which the cells were cultured and to be associated with an increased responsiveness of the mRNA levels to glucose (33).

The ectopic expression of the angiotensinogen gene in an islet cell tumor is novel and has not previously been reported in islet tumors. Although the major sites of angiotensinogen production are the liver and kidneys, it has recently been found that the gene is expressed in a large number of tissues including the brain, spinal cord, lung, colon, aorta, heart, and the adrenal glands, but not in the pancreas (16). The significance of the derepression of the angiotensinogen gene in these islet cell lines is unknown, but since it is expressed in every tumor and cell line tested, its expression might be linked to the transformation process.

The use of alternative poly(A) site selection during angiotensinogen gene transcription in the islet cells is a feature of many eukaryotic genes. The biologic consequences of the alternative polyadenylation are unknown. One may speculate that it may lead to altered stability of the mRNA in a specific tissue, splicing modifications ending in particular polypeptide products (34-38) or be without biologic consequences (38). The results presented here provide further information on the theory of a common islet stem cell and add a new dimension to the study of the rat islet cell lines. These cell lines should provide useful systems in which to delineate the biological events that take place during the developmental pathway of the islet cells.

\section{Acknowledgments}

We thank Adacie Alan and Heather Hermann for expert assistance and Janice Canniff for typing the manuscript. Jacques Philippe is supported by a Swiss National Fellowship.

The studies were supported in part by National Institues of Health grants AM-30457, AM-30834, AM-30846, and AM-32520.

\section{References}

1. McCulloch, E. A. 1983. Stem cells in normal and leukemic hemopoiesis. Blood. 62:1-13.

2. Pictet, R., and W. J. Rutter. 1972. Development of the embryonic pancreas. Endocrinology. 1:25-66.

3. Pearse, A. G. E. 1966. 5-hydroxytryptophan uptake by dog thyroid $\mathrm{C}$ cells and its possible significance in polypeptide hormone production. Nature (Lond.). 211:598-600.

4. Teitelman, G., T. H. Joh, and D. J. Reis. 1981. Transformation 
of catecholaminergic precursors into glucagon (A) cells in mouse embryonic pancreas. Proc. Natl. Acad. Sci. USA. 78:5225-5229.

5. Andrew, A. 1975. APUD cells in the endocrine pancreas and the intestine of chick embryos. Gen. Comp. Endocrinol. 26:485-495.

6. Pearse, A. G. E., and J. M. Polak. 1971. Neural crest origin of the endocrine polypeptide (APUD) cells of the gastro-intestinal tract and pancreas. Gut. 12:783-788.

7. Pearse, A. G. E. 1982. Islet cell precursors are neurons. Nature (Lond.). 295:96-97.

8. Chick, W. L., S. Warren, R. N. Chute, A. A. Like, V. Lauris, and K. C. Kitchen. 1977. A transplantable insulinoma in the rat. Proc. Natl. Acad. Sci. USA. 74:628-632.

9. Gazdar, A. F., W. L. Chick, H. K. Oie, H. L. Sims, D. L. King, G. C. Weir, and V. Lauris. 1980. Continuous, clonal, insulin- and somatostatin-secreting cell lines established from a transplantable rat islet cell tumor. Proc. Natl. Acad. Sci. USA. 77:3519-3523.

10. Oie, H. K., A. F. Gazdar, J. D. Minna, G. L. Weir, and S. B. Baylin. 1983. Clonal analysis of insulin and somatostatin secretion and L-dopa decarboxylase expression by a rat islet cell tumor. Endocrinology. 112:1070-1075.

11. Chick, W. L., M. C. Appel, G. C. Weir, A. A. Like, V. Lasuris, J. G. Porter, and R. N. Chute. 1980. Serially transplantable chemically induced rat islet cell tumor. Endocrinology. 107:954-960.

12. Chirgwin, J. M., A. E. Przybyla, R. J. MacDonald, and W. J. Rutter. 1979. Isolation of biologically active ribonucleic acid from sources enriched in ribonuclease. Biochemistry. 18:5294-5299.

13. Aviv, H., and P. Leder. 1972. Purification of biologically active globin messenger RNA by chromatography on oligothymidylic acid-cellulose. Proc. Natl. Acad. Sci. USA. 69:1408-1412.

14. Mojsov, S., G. Heinrich, I. Wilson, M. Ravazzola, L. Orci, and J. F. Habener. 1986. Preproglucagon gene expression in pancreas and intestine diversifies at the level of posttranslational processing. J. Biol. Chem. 261:11880-11889.

15. Philippe, J., D. Drucker, S. Mojsov, and J. F. Habener. 1986. Proglucagon processing in a rat islet cell line resembles phenotype of intestine rather than pancreas. Endocrinology. 119:2833-2839.

16. Campbell, D. J., and J. F. Habener. 1986. The angiotensinogen gene is expressed and differentially regulated in multiple tissues of the rat. J. Clin. Invest. 78:31-39.

17. Ohkubo, H., K. Nakayama, T. Tanaka, and S. Nakanishi. 1985. Tissue distribution of rat angiotensinogen $\mathrm{mRNA}$ and structural analysis of its heterogeneity. J. Biol. Chem. 261:319-323.

18. Larson, L. I., L. Grimelius, R. Hakanson, J. F. Rehfeld, F. Stadil, J. Holst, L. Angervall, and F. Sundler. 1975. Mixed endocrine pancreatic tumors producing several peptide hormones. Am. J. Pathol. 79:271-279.

19. Friesen, S. R. 1982. Tumors of the endocrine pancreas. N. Engl. J. Med. 306:580-590.

20. Pictet, R. L., L. B. Rall, P. Phelps, and W. J. Rutter. 1976. The neural crest and the origin of the insulin-producing and other gastrointestinal hormone-producing cells. Science (Wash. DC). 191:191-192.

21. Fontaine, J., C. Le Lievre, and N. M. Le Douarin. 1977. What is the developmental fate of the neural crest cells which migrate into the pancreas in the avian embryo. Gen. Comp. Endocrinol. 33:394-404.

22. Wiedenmann, B., W. W. Franke, C. Kuhn, R. Moll, and V. E. Gould. 1986. Synaptophysin: a marker protein for neuroendocrine cells and neoplasms. Proc. Natl. Acad. Sci. USA. 83:3500-3504.
23. Schmechel, D., P. J. Marangos, and M. Brightman. 1978. Neurone-specific enolase is a molecular marker for peripheral and central neuroendocrine cells. Nature (Lond.). 276:834-836.

24. Tapia, F. J., J. M. Polak, and A. J. A. Barbosa. 1981. Neuronespecific enolase is produced by neuroendocrine tumors. Lancet. i:808811.

25. Mercer, J. F. B., and S. A. Wake. 1985. An analysis of the rate of metallothionein mRNA poly(A)-shortening using RNA blot hybridization. Nucl. Acids Res. 13:7929-7943.

26. Marbaix, G., G. Huez, A. Burny, Y. Cleuter, E. Hubert, M Leclercq, H. Chantrenne, H. Soreq, U. Nudel, and U. Z. Littauer. 1975. Absence of polyadenylate segments in globin messenger RNA accelerates its degradation in xenopus oocytes. Proc. Natl. Acad. Sci. USA. 72:30653067.

27. Rosenthal, E. T., T. R. Tansey, and J. V. Ruderman. 1983. Sequence-specific adenylations and deadenylations accompany changes in the translation of maternal messenger RNA after fertilization of Spisula oocytes. J. Mol. Biol. 166:309-327.

28. Palatnik, C. M., C. Wilkins, and A. Jacobsen. 1984. Translational control during early dictyostelium development: possible involvement of poly(A) sequences. Cell. 36:1017-1025.

29. Doel, M. T., and N. H. Carey. 1976. The translational capacity of deadenylated ovalbumin messenger RNA. Cell. 8:51-58.

30. Jacobson, A., and M. Farreau. 1983. Possible involvement of poly(A) in protein synthesis. Nucl. Acids. Res. 11:6353-6366.

31. Kakita K., S. J. Giddings, P. S. Rotwein, and M. A. Permutt. 1983. Insulin gene expression in the developing rat pancreas. Diabetes. 32:691-696.

32. Guggenheim, N. Z., and M. A. Permutt. 1986. Identical transcription initiation sites for proinsulin messenger ribonucleic acid in three insulin-expressing tissues. Endocrinology. 118:1710-1715.

33. Muschel, R., G. Khoury, and L. M. Reid. 1986. Regulation of insulin mRNA abundance and adenylation: dependence on hormones and matrix substrata. Mol. Cell. Biol. 6:337-341.

34. Amara, S. G., V. Jonas, M. G. Rosenfeld, E. S. Ong, and R. M. Evans. 1982. Alternative RNA processing in calcitonin gene expression generates mRNAs encoding different polypeptide products. Nature (Lond.). 298:240-244.

35. Rosenfeld, M. G., J. J. Mermod, S. G. Amara, L. W. Swanson, P. E. Sawchenko, J. Rivier, W. W. Vale, and R. M. Evans. 1983. Production of a novel neuropeptide encoded by the calcitonin gene via tissuespecific RNA processing. Nature (Lond.). 304:129-135.

36. Alt, F. W., A. L. M. Bothwell, M. Knapp, E. Siden, E. Mather, M. Koshland, and D. Baltimore. 1980. Synthesis of secreted and membrane-bound immunoglobulin mu heavy chains is directed by mRNAs that differ in their $3^{\prime}$ end. Cell. 20:293-301.

37. Schwarzbauer, J. E., J. W. Tamkun, I. R. Lemischka, and R. O. Hynes. 1983. Three different fibronectin mRNAs arise by alternative splicing within the coding region. Cell. 35:421-431.

38. Setzer, D. R., M. McGrogan, and R. T. Schimke. 1982. Nucleotide sequence surrounding multiple polyadenylation sites in the mouse dihydrofolate reductase gene. J. Biol. Chem. 257:5143-5147.

39. Philippe, D., J. Drucker, and J. F. Habener. 1987. Transcriptional regulation of genes encoding insulin, glucagon and angiotensinogen by sodium butyrate in a rat islet cell line. $\mathrm{Mol}$. Cell. Biol. In press. 